\title{
De-centring Managua: post-earthquake reconstruction and revolution in Nicaragua
}

\author{
DAVID JOHNSON LEE
}

Temple University, 1801 N. Broad Street, Philadelphia, PA 19122, USA

\begin{abstract}
The reconstruction of Managua following the 1972 earthquake laid bare the contradictions of modernization theory that justified the US alliance with Latin American dictators in the name of democracy in the Cold War. Based on an idealized model of urban development, US planners developed a plan to 'decentralize' both the city of Managua and the power of the US-backed Somoza dictatorship. In the process, they helped augment the power of the dictator and create a city its inhabitants found intolerable. The collective rejection of the city, the dictator and his alliance with the United States, helped propel Nicaragua toward its 1979 revolution and turned the country into a Cold War battleground.
\end{abstract}

On 23 December 1972, the capital city of Nicaragua was destroyed by an earthquake, and it has never been rebuilt. This is the consensus of many of Managua's residents, its foreign visitors and the academic community. They agree that the country's dictator, General Anastasio Somoza Debayle, used the international relief funds which flooded into the country after the earthquake to reward cronies and augment his own power rather than rebuild what had once been the vital centre of a thriving metropolis. This failed reconstruction of Managua is given credit for setting off the chain of events that led to the 1979 overthrow of the Somoza regime and the Sandinista revolution. ${ }^{1}$

Managua's old city centre is today a disorganized mixture of open spaces interspersed with decaying monuments, low-income housing and scattered commercial activity. Wherever the beating heart of the city lies, it is not there. The city's shape has been likened to a 'deformed octopus', spread out along a series of multilane highways that connect a multitude of nodes of private life and commercial activity, each section identifiable by the socio-economic status of its population. ${ }^{2}$ The old city remains

${ }^{1}$ C. Vilas, The Sandinista Revolution: National Liberation and Social Transformation in Central America (New York, 1986), 101; B. Diederich, Somoza and the Legacy of US Involvement in Central America (New York, 1981).

2 D. Wall, 'City profile: Managua', Cities, 13 (1996), 45-52. On contemporary Managua's class character, see D. Rodgers, 'A symptom called Managua', New Left Review, 49 (Jan.-Feb. 2008), 103-20. 
embedded in the culture and practice of contemporary Managuans, who still use landmarks destroyed by the earthquake to orient themselves and visitors. ${ }^{3}$ Residents of the old Managua oriented themselves around the city's geography, referring to east and west as arriba and abajo, where the sun rises and sets, and north and south as al lago and a la montaña, toward Lake Xolotlán and toward the hill called Loma de Tiscapa at the southern edge of the old downtown. ${ }^{4}$ Though the sun rises and sets as always, and the lake remains Managua's northern edge, the city's centre now lies well south of Loma de Tiscapa. This hill was where the presidential palace and political prison overlooked the city for the 40 year duration of the Somoza family's dynasty, and it remains an unconscious point of orientation long after the dynasty has fallen and the city itself has moved.

Despite appearances, Managua was rebuilt after the earthquake according to a design. The earthquake devastated the old Managua of crowded streets and small business, where people of different economic strata lived in close if sometimes tense proximity. The permanent destruction of the old city was, however, man-made. The new Managua which took its place was the product of a plan to 'decentralize' the metropolis. The old downtown was fenced off to prevent redevelopment, and a new city was encouraged to spread out around the old. This new city, planners believed, would encourage more rational urban development than was possible in the old congested and dangerous city centre. They also thought that more modern urban development would resolve the central problem of authoritarian rule in Nicaragua. In the name of safety, economic efficiency, social harmony and, most of all, deeply contradictory ideas of modernization, the Somoza regime, US and international planners and private enterprise rebuilt Managua in a way that did not ease social tensions but augmented them and helped bring about the last major social revolution of the Cold War.

Planners and politicians in the US and Nicaragua reconstructed Managua around a vision of a modern, orderly city whose very structure would encourage economic growth and political participation. Built into the model of urban development exported by the United States to Nicaragua and countries like it was a tension between the need for centralized planning to ensure rational economic growth and community development to ensure equity and democratic accountability. The attempt to export this model remade the urban fabric of Managua on a grand scale, and fostered popular discontent and urban rebellion on an even grander scale, much like in the US itself during the 1960s. ${ }^{5}$

3 'La direcciones de Managua: de donde... ', La Prensa (LP), 22 Dec. 2002.

${ }^{4} \mathrm{~J}$. Freeman, 'From the little tree, half a block toward the lake: popular geography and symbolic discontent in post-Sandinista Managua', Antipode, 42 (2010), 336-73.

5 The model was exported even as it was being questioned in the US itself. See W. Pritchet, 'Which urban crisis?: regionalism, race, and urban policy, 1960-1974', Journal of Urban History, 34 (2008), 266-86. 
The Cold War in the global south was a struggle between alternate visions of modernity offered by east and west, and the United States failed to construct the ultimate symbol of modernity in Nicaragua, a dynamic metropolis. ${ }^{6}$ The new Managua that took shape following the earthquake conformed in many ways to its planners' design. It was safer from natural disaster, spread out away from its old centre. It was also more conducive to planning and development, divided by class and economic function in the fashion of North American cities. It did not, however, limit the power of the dictatorship, but rather both augmented it and inscribed it into the structure of the city itself. The collective rejection of this new city would create an unlikely alliance of the Nicaraguan bourgeoisie, the radical left and Managua's poor, against the Somoza dynasty and its US backers. This alliance began to unite around a rejection of both the dictatorship and the new, modernized Managua that it had built. The beginnings of a revolutionary alliance of the right and left coalesced around an alternative vision of urban space as the place where national identity and class harmony resided. ${ }^{7}$ Their efforts would bring about the 1979 Sandinista Revolution and make Managua into a Cold War city, a place where the dissonance between the promise and reality of modernization led to revolt against the new city and the geopolitical order that brought it about.

\section{Developmentalism, democracy and the Somoza dynasty before the earthquake}

From 1936, when Anastasio Somoza García took power, until 1979, when his second son Anastasio Somoza Debayle was overthrown, the Somoza regime and the city of Managua were the centre of the political and economic life of Nicaragua. Managua was chosen as the site for the capital of Nicaragua in the nineteenth century as a compromise between the warring oligarchies of the cities of León and Granada. It was destroyed by an earthquake in 1931 and reconstructed along the Spanish colonial model: a grid of streets centred on a cathedral and plaza. Somoza García built his power in the 1930s first as head of the US-created Guardia Nacional and then as president of Nicaragua, artfully cultivating and manipulating the traditional landed elite, Nicaragua's workers and the US government. The power of the city and the dynasty grew in tandem, and their symbiosis embodied both the promise and peril of the modernization process that United States and Latin American elites propagated as a pan-American ideal. As Managua grew, so grew the power of the Somoza family, whose presidential palace loomed over the city's thriving commercial centre. ${ }^{8}$

${ }^{6}$ O.A. Westad, The Global Cold War: Third World Interventions and the Making of our Times (Cambridge, 2005).

7 On the importance of studying nationalism and urban space, see V. Bickford-Smith, 'Introduction: the case for studying cities and nationalisms', Journal of Urban History, 38 (2012), 855-61.

8 K. Walter, The Regime of Anastasio Somoza, 1936-1956 (Chapel Hill, 1993). 
Managua's population growth began to accelerate in the 1950s thanks to a booming agro-industry in the countryside geared toward cotton export, growing from 40,000 in1920 to 400,000 in 1972 and from a quarter to half the country's urban population. ${ }^{9}$ Consolidation of land in the countryside combined with growth in small urban industry brought by Nicaragua's new wealth caused peasants to migrate in large numbers to cities. Though Nicaragua's smaller cities experienced some growth, the largest economic expansion took place in the capital, which was home to most of the nation's industrial development. In the boom years of the 1950s and 1960s, the downtown area's tightly packed streets became the site of burgeoning commerce and consumption by a small but growing Nicaraguan middle class. $^{10}$

Nicaragua was in the 1960s a showcase for the possibilities of the Alliance for Progress in Latin America. ${ }^{11}$ The US-supported vision of a 'modernized' Latin America as the best antidote to communism accepted the growth of large urban areas and the consolidation of the agroexport economy as necessary and desirable outcomes of Latin America's modernizing process. Early proponents of modernization theory argued that urbanization was essential to the creation of both a state and people with capabilities and worldviews necessary for living in the modern world. ${ }^{12}$ Programmes related to housing and urbanization were focal points of the Alliance for Progress, and the US government spent millions of dollars to develop housing projects throughout Latin America. In a small country like Nicaragua, modernizers argued that the growth of a single 'primate' city to dominate the country was unavoidable. Such a metropolis would be a boon to development planners, giving them the opportunity to reach more easily the poor who were the targets of their programmes. ${ }^{13}$

The two sons of Somoza García, who ruled Nicaragua jointly after their father's assassination in 1956, embodied the two pillars of the US alliance, economic progress and military power. Luis Somoza Debayle, president from 1956 to 1963, encouraged a more technocratic form of governance, cultivating allies at the Central American Institute of Business Administration (INCAE) in Managua, which had been founded in 1963 in co-operation between the Nicaraguan private sector, Harvard University and USAID. Anastasio Somoza Debayle took his father's place as head of the Guardia Nacional, and replaced his brother as president in 1967. The US government accepted that the Somoza family's rule in Nicaragua was based on military force, and it provided military aid alongside

${ }^{9}$ Wall, 'City profile: Managua', 47.

${ }^{10}$ G. Ortega R., Reconstrucción Histórica y Gráfica de Managua Anterior al Terremoto de 1972 (Managua, n.d.).

${ }^{11}$ M. Latham, Modernization as Ideology: American Social Science and 'Nation-Building' in the Kennedy Era (Chapel Hill, 2000).

12 D. Lerner, The Passing of Traditional Society: Modernizing the Middle East (Glencoe, 1958), 60.

${ }^{13}$ National Archives and Records Administration (NARA), USAID Nicaragua Country Files1973-75 (NCF), box 10, 'Guidance statement on urban development', 15 Jun. 1973. 
economic development aid. In an attempt to improve the military's image, USAID sponsored a programme in the 1960s to rebrand the Guardia as an urban civilian police force instead of a praetorian guard. USAID provided uniforms and small arms to distinguish the police from the army and thus ameliorate the appearance of Managua as a city under military occupation. The police nevertheless remained part of the Guardia and under control of Somoza. On USAID's advice, Somoza gave them new functions such as enforcing traffic laws and created a unit composed solely of women to help mitigate the dictatorship's brutal image. ${ }^{14}$

The Nicaraguan government was subject to occasional attempts at insurrection from both the right and the left. The Frente Sandinista de Liberación Nacional (FSLN), a radical leftist group inspired by the Cuban Revolution, at the end of the 1960s maintained a small but dedicated force of armed revolutionaries. It staged a number of daring but ultimately fruitless attacks, which proved it capable and willing to maintain its armed struggle against the regime. Though US intelligence saw no likelihood of insurgent success, the threat provided Somoza with an important tool for maintaining US support. ${ }^{15}$ Nicaragua's conservative elite also attempted to foster urban rebellion. A 1967 bid for power left hundreds dead in Managua, and the opposition elite created a political compromise with Somoza.

Richard Nixon's election as US president in 1968 seemed to herald a broad change in US approaches to Latin America. Nixon was critical of both the domestic attempts of Presidents Kennedy and Johnson to confront problems of race and urban poverty and their attempts to promote democracy and development around the world. He held that the Alliance for Progress had not improved conditions in Latin America at all. ${ }^{16}$ His choice for ambassador to Nicaragua, Turner Shelton, was known less for his diplomatic savvy than for his closeness to Nixon's inner circle and his ties to shadowy businessmen like Howard Hughes. Shelton quickly became renowned in Nicaragua for his obsequious behaviour toward Somoza. Many observers complained that he behaved more like a courtier than an ambassador. ${ }^{17}$ Though aid budgets and staff were cut for many countries, Nicaragua's funding remained strong, as did the fundamental premise that US aid should support development, democracy and stability. Though the term 'Alliance for Progress' quietly fell into disuse as a relic of an earlier era, the bureaucracies created to administer aid churned on. ${ }^{18}$ Administrators

14 'Organizan cuerpo femenino de policía', LP, 30 Mar. 1974.

${ }^{15}$ M. Gambone, Capturing the Revolution: The United States, Central America, and Nicaragua, 1961-1972 (Westport, 2001).

16 'Address by Richard M. Nixon to the Bohemian Club', Foreign Relations of the United States, 1969-76, vol. I, Foundations of Foreign Policy, 1969-72, document 2 (United States Government Printing Office, 2005).

17 See A. Lake, Somoza Falling (Boston, 1989).

18 J. Taffet, Foreign Aid as Foreign Policy: The Alliance for Progress in Latin America (New York, 2007). 
trained under the Alliance's auspices continued their work of modernizing countries like Nicaragua.

Nicaragua up until 1972 continued a cycle of boom and bust in agriculture and outbreaks of political violence followed by repression and stability. Rather than following an inexorable path toward progress or languishing in backwardness, Nicaraguan political and social life was subject to seemingly endless gyrations that never quite reached the full momentum of revolution. Neither the socialist vision propagated by Cuba and the FSLN nor the capitalist takeoff prescribed and predicted by modernizers came to pass. Only a cataclysmic event would break the cycle and set in motion a radical transformation.

\section{Managua terremoteada: reconstruction and decentralization}

The earthquake that struck Managua the night of 23 December 1972 measured 6.2 on the Richter scale, relatively small for such a massively destructive event. Nonetheless, 10,000 Managuans lost their lives, 20,000 were seriously injured and 250,000 were left homeless. The earthquake laid waste to the city's commercial, governmental and residential core. Its special destructive force was due to the fact that it took place very close to the surface and virtually in the centre of Managua's highly concentrated downtown area, under which lay three major fault lines. The homes of the poor and middle classes that were concentrated in the city centre and constructed of taquezal, structures of wood and mud, fell immediately. Many government and commercial buildings made of steel and concrete cracked and collapsed in on themselves. Only a handful of buildings of recent construction remained standing. After the shaking subsided, the closely packed buildings provided fodder for a fire that lasted for days. The city's fire trucks lay under rubble. ${ }^{19}$

In response to news of a destroyed city which observers compared to Hiroshima or Nagasaki, aid poured into Nicaragua from all over the world..$^{20}$ Somoza initially was powerless to deal with the situation, as the Guardia dissolved spontaneously and began to help family members flee or participate in the widespread looting. Order was restored by the declaration of martial law and the assistance of US troops from the Canal Zone. The Guardia took control over distribution of relief aid, and rumours began to spread of misappropriation by the regime. The US embassy recognized that some aid had been misused, but held that this was due to the unusual circumstances of chaos as opposed to the inherent corruption of the regime. ${ }^{21}$ As the majority of Managua's residents fled either to the

19 'Case report: Nicaragua-earthquake, December 1972' (Agency for International Development, 1973).

20 'Super-bid due in Nicaragua', Wrecking and Salvage Journal (Jul. 1973), 9. See also E. Aguirre, Un sol sobre Managua (Managua, 1998), 63.

${ }^{21}$ NARA, Department of State, Inter-American Affairs, Records Relating to Nicaragua, 196375 (DSIAA-RRN), container 6, memorandum from George W. Phillips, 5 Jan. 1973. 


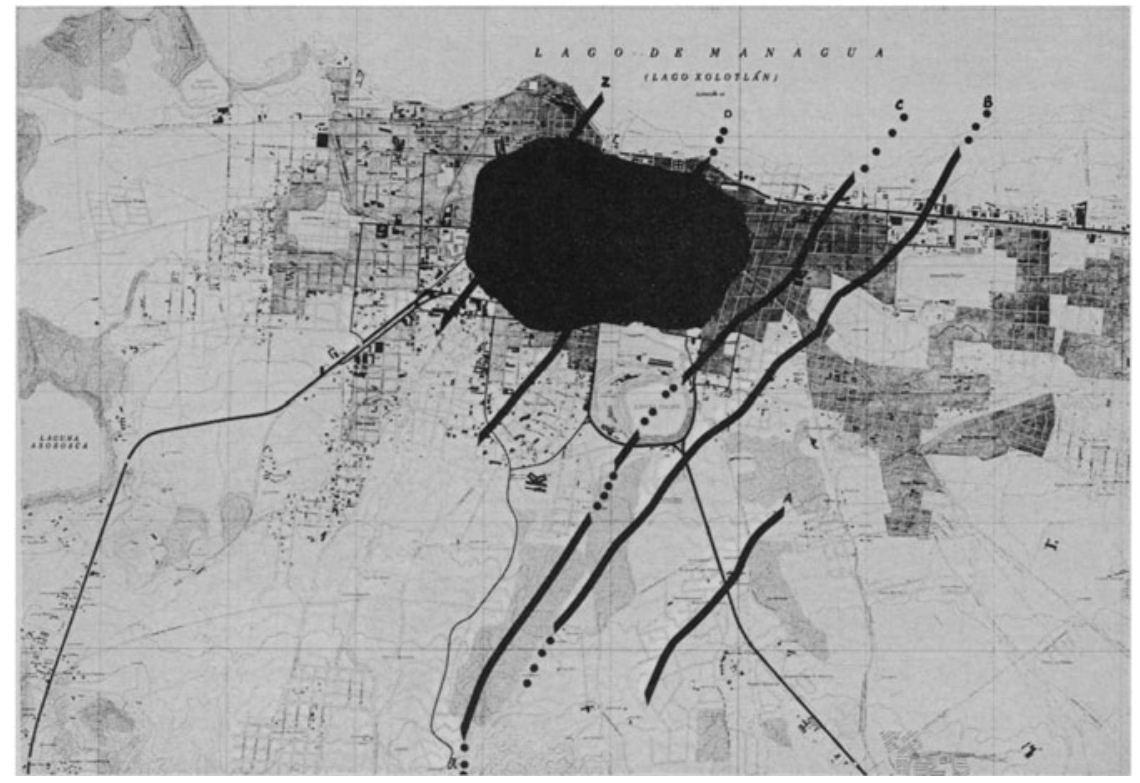

Figure 1: A graphic illustration of the totality of the downtown's destruction, showing the city's numerous fault lines Source: R. Kates, J.E. Haas, D.J. Amaral, R.A. Olson, R. Ramos and R. Olson, 'Human impact of the Managua earthquake', Science, 182 (7 Dec. 1973), 984.

city's outskirts or to other nearby towns, General Somoza ordered the downtown evacuated and surrounded it with barbed wire.

Given the near total destruction of downtown Managua, as depicted in Figure 1, rebuilding the city gave planners and politicians the opportunity to design an entirely new urban space. And as Managua was universally perceived as the vital centre of Nicaragua, to reimagine Managua was to open the possibility of a reimagined Nicaragua. The most fundamental and obvious fact about life in Nicaragua - that its political and economic life was almost totally dominated by one man - was also the most difficult to address directly. After the earthquake, Somoza declared himself the head of the Emergency Reconstruction Committee and made little attempt to disguise his near total power. For US policy-makers, the problem of what to do with Somoza was pivotal, but the delicate political situation deterred openly debating a solution. Ambassador Shelton and President Nixon never wavered in their support for Somoza. ${ }^{22}$

22 Foreign Relations of the United States, vol. E-10, Documents on American Republics, 1969-72, document 43. 
The week after the earthquake, President Nixon devised a plan to use the disaster as an opportunity to advertise US generosity and support for Nicaragua by flying in person to the ruined city to deliver an aid cheque and bring supplies. ${ }^{23}$ His advisers warned him that such a stunt could backfire, not only because there were still decaying bodies and possibly live people under the rubble. They also warned him that the images of the president in the middle of a destroyed city might remind Americans of the war in Vietnam. It might also remind them of their country's own urban crisis and lead them to ask: 'why are you worried about Nicaragua and you're not worried about our inner cities here?' The trip was cancelled, and Nixon sent a special envoy instead. ${ }^{24}$

Though America's conflict-ridden cities in the 1970s might seem to have offered little worth emulating, they were nonetheless taken by the planners who worked to reconceive Managua as models for reconstructing Nicaragua. A group of experts who came to Managua to conduct a comparative study of post-disaster development looked for precedent to the 1906 earthquake that devastated San Francisco. Ignoring the vastly different circumstances in Managua and San Francisco, they took the latter's recovery and subsequent development into one of the continent's wealthiest cities as 'the normal evolutionary model of urban growth in the wake of disaster'. ${ }^{25}$ In their report, which would be cited repeatedly in decades to come, these specialists argued that the segregation of urban commercial from residential space and the segregation of the rich from the poor were inevitable processes that the earthquake had simply sped up. This evolutionary assumption that Nicaragua would, with the help of benevolent professionals, simply recapitulate the history of the United States from an earlier era underlay the consensus about planning. ${ }^{26}$

Because US aid programmes had been designed around a liberal vision of Nicaragua's future modelled after their own country, many planners and state department officials were less comfortable than Nixon and Shelton with giving Somoza uncritical support in reconstructing the city. Many members of the Nicaraguan elite were also critical of Somoza. The opposition Partido Conservador, however, had consented to a 'pact' of alliance with the general, guaranteeing their representation in the rubber stamp legislature in exchange for co-operation. The regime's most vocal opponent Pedro Joaquín Chamorro, the editor of the opposition paper $\mathrm{La}$ Prensa, lambasted the regime but was unable to form a coherent political movement. ${ }^{27}$ All agreed that Managua must be reconstructed, but they

${ }^{23}$ White House Telephone, Conversation \#035-013; 12-27-1972; White House Tapes; Richard Nixon Presidential Library and Museum, Yorba Linda, California.

${ }^{24}$ Executive Office Building, Conversation \#380-001a; 12-28-1972; White House Tapes; Richard Nixon Presidential Library and Museum, Yorba Linda, California.

25 J.E. Haas, R.W. Kates and M.J. Bowden (eds.), Reconstruction following Disaster (Cambridge, 1977), 69.

${ }^{26}$ Ibid., 108-9.

27 P.J. Chamorro, Diario politico (Managua, 1990). 
first had to reconcile the problem of dictatorship with the promise of liberal development.

The many different interested parties in the development of postearthquake Nicaragua ultimately reached a consensus on how city and country could be reconstructed while maintaining the appearance that US aid supported democracy. That consensus was built around the idea of 'deconcentration' or 'decentralization' of the city of Managua, and of Managua itself within the life of the country. The politicians and planners involved came to agree that the city of Managua would be safer and more economically viable if rebuilt in a more dispersed manner, instead of allowing the unstable centre once again to serve as the heart and nerve centre of the city's life. ${ }^{28}$ They also agreed that in lieu of focusing development solely on Managua, the city could be made safer and the country more prosperous by encouraging development in Nicaragua's other cities as well as in the countryside. Where the participants to this consensus disagreed was in assessing the effects this decentralized development would have. For planners and US officials wary of Somoza's ability to reconstruct a viable city, decentralizing development would promote a dispersal of power in the country and enact modernization theory's claim that modern economic growth undermined dictatorial control. For those who saw Somoza as 'indispensable' for the continued stability of the country, this dispersal of power would actually increase the dictator's control by creating more modern and efficient tools of government which would remain indefinitely in one man's hands.

Nicaragua's catastrophe, and its government's close relationship with the United States, made it a proving ground for evolving ideas about modernization theory in urban environments. The problem of decentralization reflects the core issue of power under modernization theory's paradigm for development. ${ }^{29}$ In its classical conception, modernization theory imagined societies developing as organic wholes in which economy and society are intimately linked. For theorists who took western Europe and the United States as paragons of development, richer societies possessed institutions of government that worked in harmony with market forces to drive industrial and agricultural concentration and growth. The expansion of education and economic opportunity created an informed citizenry which held its government accountable to provide necessary services. Further, because excessive concentration of centralized power overtaxed bureaucratic capacity, the expansion of government power must be accompanied by the 'devolution' of authority to local governments in the name of more efficient governance. Such devolution encouraged citizen participation. Local governments would

${ }^{28}$ R. Kates, J.E. Haas, D.J. Amaral, R.A. Olson, R. Ramos and R. Olson, 'Human impact of the Managua earthquake', Science, 182 (7 Dec. 1973), 988-9.

${ }^{29}$ On the intellectual foundations, see N. Gilman, Mandarins of the Future: Modernization Theory in Cold War America (Baltimore, 2003). 
be more accessible and encourage a mutual process of learning on the part of citizens and administrators..$^{30}$

The plan to decentralize power in Nicaragua had three parts, which drew on the latest social scientific ideas on governance and development. First, 'secondary cities' would be built up as alternative sites of development. The cities of Granada and León, old centres of power and wealth which had been supplanted by the growth of Managua, became home to tens of thousands of refugees after the earthquake. Foreign aid and investment would be directed there both by the government and international agencies to foster growth and provide incentive to keep refugees from returning to Managua. ${ }^{31}$ Second, an agricultural credit programme would aid small farmers in order to mitigate the concentration of land and wealth brought by agro-export driven modernization. This programme would also build the allegiance of campesinos to the government instead of to insurgents. ${ }^{32}$ Finally, co-operatives and community development organizations would help the Nicaraguan people construct local political structures that would foster economic co-operation and enable them to express their needs and grievances to the government. ${ }^{33}$

In the minds of Somoza and his political allies, the process of dispersing power would not weaken the dictator. To the contrary, building governmental powers of planning and institutions of development not just in Managua but all over Nicaragua would allow the centre of government, in the hands of Somoza himself, to exert its control more rationally and effectively over the country's entire territory. Land in the old city centre had been owned by an economic elite that was not totally beholden to him. Somoza saw redevelopment outside the centre as a means to increase the ties of the middle class to his own power rather than that of his political rivals. ${ }^{34}$ In a rationalized Managua, new barrios would house workers near their sources of employment in industry and allow for greater government supervision. The poorest portion of Managua's population would be encouraged to stay out of Managua altogether. They would reside either in Nicaragua's other cities where they had fled after the earthquake or establish settlements on the 'frontier' lands being developed in the east. ${ }^{35}$

Members of the US embassy and the State Department were less sanguine than Ambassador Shelton about the future of Nicaragua should Somoza remain in power. They argued that the leverage provided by

${ }^{30}$ H. Maddick, Democracy, Decentralisation and Development (London, 1963).

31 D. Rondinelli, Secondary Cities in Developing Countries: Policies for Diffusing Urbanization (London, 1983).

32 USAID Evaluation, 'Nicaragua - rural development sector loan' (USAID, 1975); NARA, Central Foreign Policy Files, 7/1/1973 - 12/31/1976 (CFPF), 'Conversation with President Somoza concerning rural development', 30 Sep. 1975.

33 'Community development - Nicaragua' (USAID, 1974).

34 NARA/CFPF, 'Courtesy call on General Somoza by General Wm. Rosson, CINCSO, 3-17$1973^{\prime}$.

35 NARA/DSIAA-RRN, container 6, memorandum Allison Herrick to Peter Orr, 13 Jan. 1975. 
increasing economic assistance after the earthquake should be used to encourage a democratic opening of the regime, rather than a tightening of the general's already firm hold on the country. ${ }^{36}$ As a means of distancing itself from direct responsibility for Somoza's rule, the US encouraged international organizations to play a visible role in the reconstruction process, even as US agencies helped Somoza to orchestrate the entire mechanism. USAID co-ordinated its work with the World Bank, the InterAmerican Development Bank, the United Nations and the Organization of American States, in addition to a large number of countries and private aid associations. These organizations likewise offered funding and advice. Still, because of the close relationship between Somoza and the US government, USAID was at the centre of these efforts. The agency was charged not just with providing aid and planning advice but also building a planning apparatus within the Nicaraguan government itself. ${ }^{37}$

USAID tasked urban planning specialists from Harvard and the University of California at Berkeley with providing advice not only on how to reconstruct the city. They also offered recommendations on how to reconstruct the government in order to oversee the city's orderly growth. ${ }^{38}$ Lawrence Mann and Wilhelm von Moltke of Harvard were prominent urban designers charged with helping co-ordinate development in Nicaragua. Von Moltke had been involved with an earlier landmark Latin American project to create a new city, Ciudad Guayana in Venezuela. ${ }^{39}$

In their reports they argued that Managua could be rebuilt in a more efficient manner should decision-making devolve from a single authority to a wider spectrum of public opinion. More rational city planning, they explained, would result from less 'authoritarian control'. ${ }^{40}$ US planners worked with the technocratic elite at INCAE, who greeted the prospect of decentralization with carefully calibrated enthusiasm. ${ }^{41}$ Rather than speaking openly of dethroning Somoza, they argued that decentralization would 'remove power from central authority' and place it in the hands of competent administrators like themselves. ${ }^{42}$ Given the fact that any decision to devolve authority must come from Somoza himself, their plans were couched in narrowly technical language and relied on the ideas of efficiency and productivity that were the hallmarks of technocratic modernization. Though INCAE's and USAID's planners obliquely criticized Somoza's control of the planning process, they

36 NARA/DSIAA-RRN, container 7, letter from Leland Warner to Stuart Lippe, 15 Mar. 1973.

37 NARA/NCF, box 10, 'Memorandum for the Development Assistance Executive Subcommittee, subject: intensive review request, loan title: earthquake recoveryreconstruction/deconcentration', 8, 13 .

${ }^{38}$ L. Mann, 'Evaluation of Managua reconstruction planning' (USAID, 6-6-75).

${ }^{39}$ L. Peattie, Planning: Rethinking Ciudad Guayana (Ann Arbor, 1987).

${ }^{40}$ L. Mann and W. von Moltke, 'Report on a process of planning and urban design for the reconstruction and development of Managua' (Harvard University Graduate School of Design, 1973).

${ }^{41}$ M. Everingham, Revolution and the Multiclass Coalition in Nicaragua (Pittsburgh, 1996), 113.

42 F. Sánchez S. and E. Terán G., Sobre la descentralización (Managua, 1973). 
contributed to the programmes and apparatus which would allow him to dominate the city's future development.

The first plan for reconstructing the 'new' Managua was created by a team of urban designers from the Mexican Ministry of Public Works, who had begun studying ways to modernize the old city's downtown before the earthquake. ${ }^{43}$ Once the disaster struck, they hastily updated their plans in an attempt to create a master plan for the city, though without incorporating into their revisions extensive on-site study or consultation with the Nicaraguans themselves. The new city they envisioned was one modelled after Mexico City. The downtown area would be rebuilt with high-rise residential buildings, government offices and green spaces, with a much lower population density but preserving the city centre's old status as the axis around which the metropolis would grow. US advisers rejected this plan as totally unsuited to Nicaragua for financial and social reasons. The modernist high rises in which Managuans were to live and work were socially unacceptable, thought the advisers, because they were too alien to the population's traditional experience. ${ }^{44}$ They urged the planners to keep their expectations low and remember that Managua 'will always be a small and quite poor city'. A danger in bringing in foreign contractors to design housing, they feared, was that they might not be able to set their sights low enough for what was appropriate for Nicaragua. ${ }^{45}$

Mixed with this lowering of expectations by planners, however, was another tendency: to imagine Managua as another Los Angeles. This model featured new highways intended to allow the population to spread out and enjoy great freedom of mobility. According to the International Panel on Reconstruction and Redevelopment, the new Managua 'will be more modern in that it will reflect the tendency observable in all parts of the world toward greater expansion of urban area than in urban population. There should, however, be no loss of accessibility, specifically as good surface transportation is made a top priority and as vehicular ownership continues to grow - which is to be expected. ${ }^{\prime 46}$ In keeping with US development policy's emphasis on infrastructure as a primary motivator of development, US post-earthquake aid was poured into road construction. According to Nicaragua's Ministry of Planning, the destruction of the old city's core was a blessing. The congested streets of the old downtown could now be replaced by wide boulevards, easing the flow of vehicular traffic

${ }^{43}$ For a description, see 'Nicaragua urban sector loan - Managua reconstruction' (Agency for International Development, 1974), 10-12.

44 NARA/CFPF, 1973STATE062298, 'Managua reconstruction: IBRD Panel', Apr. 1973.

45 NARA/CFPF, J. Osborn, 'Geographic/demographic problems of post-earthquake development in Nicaragua', 14.

46 'International Advisory Panel on Reconstruction and Redevelopment of the Managua Region', Mar. 1973, cited in A. Kreimer, 'Post-disaster reconstruction planning: the cases of Nicaragua and Guatemala', Mass Emergencies, 3 (1978). 


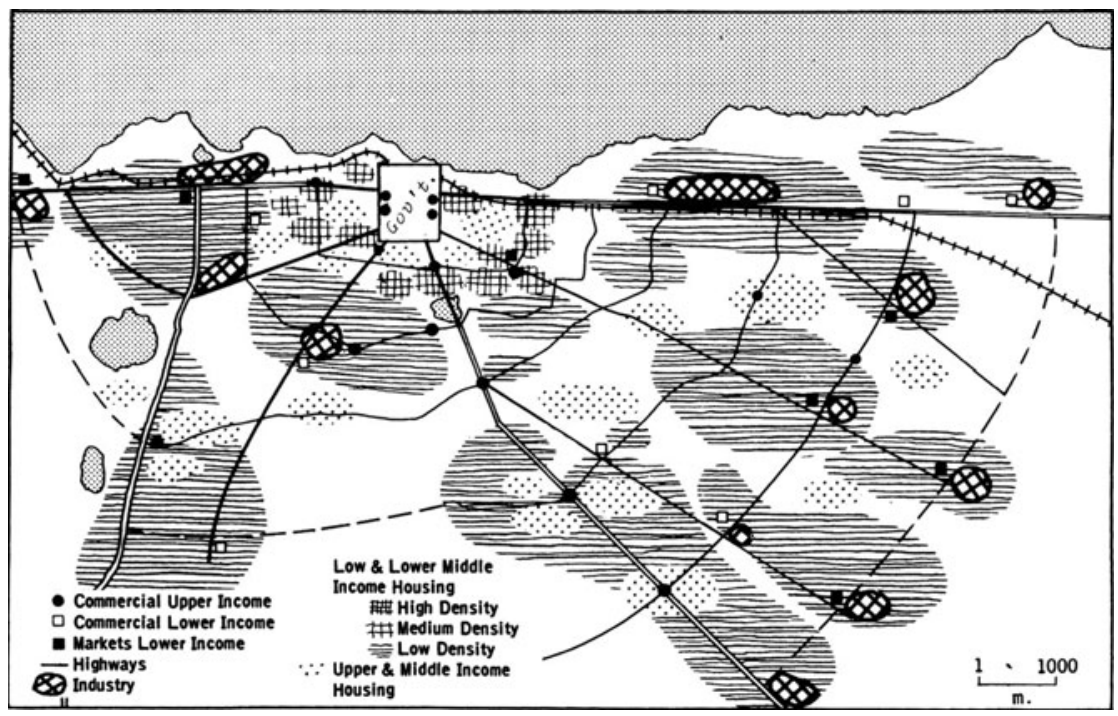

Figure 2: Planners' vision of a decentralized Managua, with an unspecified 'government' at the centre Source: J.E. Haas, R.W. Kates and M.J. Bowden (eds.), Reconstruction following Disaster (Cambridge, 1977), 241.

and commerce. ${ }^{47}$ US aid was put toward building a 'By-pass' around the old city centre. Other highways linking Managua to nearby cities would both support the decentralized metropolitan area and provide locations for new development (Figure 2).

The new roads were constructed using labour-intensive adoquines (paving stones) and thus presented employment opportunities for earthquake victims. ${ }^{48}$ The loan requests neglected to mention that the Somoza family was the primary producer for the paving stones for the new highways. ${ }^{49}$ US aid agencies also overlooked the fact that individuals close to the government were using knowledge of development plans to buy land and reap enormous profits. Though many US officials were opposed to the expansion of Somoza's economic power, they rationalized that, given Somoza's expansive hold over the economy, it was impossible to plan the city in such a way that he would not benefit. ${ }^{50}$

47 Informe Nacional de Nicaragua. Reunión regional Caracas, Venezuela, Presentado por Vice Ministro de Planificación Urbana Iván Osorio Peters (Vice Ministerio de Planificación Urbana, 1976).

48 'Proposal and Recommendations for the Review of the Development Loan Committee, Nicaragua - Program Loan, 1-31-73' (Agency for International Development, 1973).

49 'La Reconstruction Official de Managua', LP, 11 Aug. 1974.

${ }^{50}$ NARA/DSIAA-RRN, 'Supplementary CASP Guidance - Nicaragua'. 


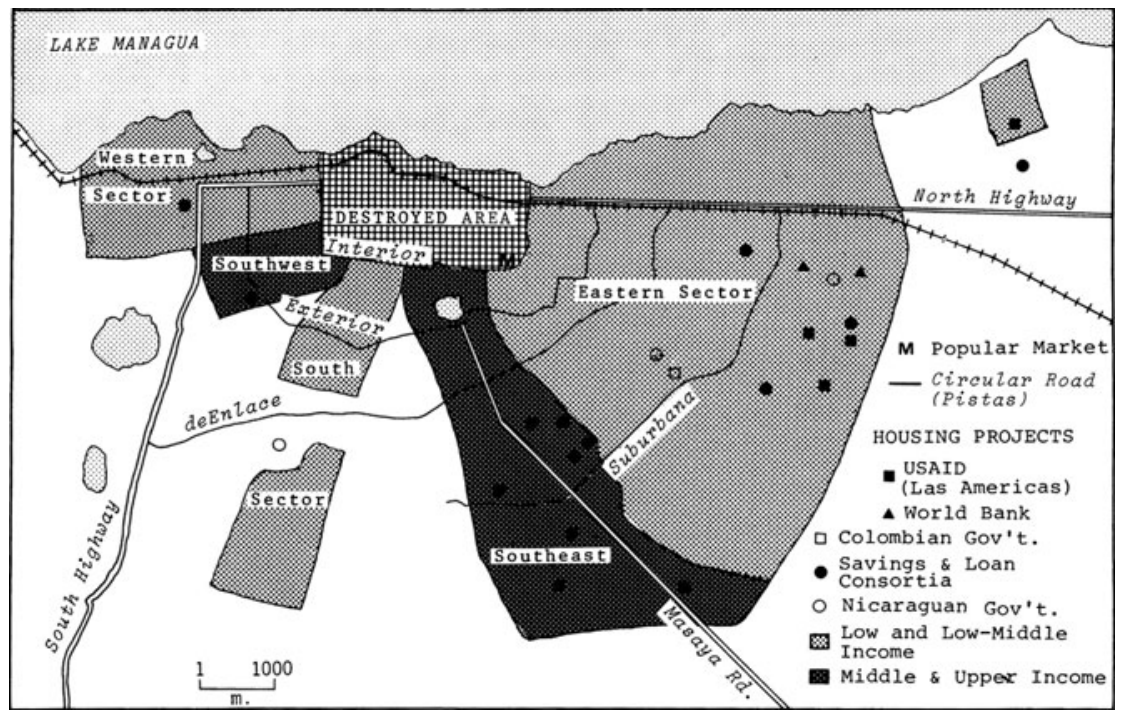

Figure 3: Illustration of post-earthquake Managua, showing the class structure of the emerging city; housing projects were deliberately placed in areas marked as 'low income'

Source: Haas, Kates and Bowden (eds.), Reconstruction following Disaster, 133.

The way that planners synthesized the idea of a 'small and poor' Managua with an automobile-friendly consumer metropolis was by essentially dividing Managua up into a number of distinct cities, or selfsufficient 'nuclei', which would then be tied together by the new roadways (Figure 3). One of these cities would belong to the affluent rising middle class, who could aspire to owning a home on the outskirts of the city. Privately financed housing developments began to spring up after the earthquake, and planners expected their residents to use the new highways to commute to work and participate in Managua's new consumer boom. ${ }^{51}$ New shopping centres designed to take advantage of the city's new infrastructure grew up around the periphery of the old city. Developers understood that many Managuans had lost their sense of community with the loss of the downtown. Those responsible for the largest and most luxurious of the new shopping centres constructed around the new development 'pole' in the southern part of the city advertised that they had recreated the streets of old Managua indoors. Of course, this new Managua would belong exclusively to the elite, as the shopping centre could only effectively be reached by car. Developers consciously evoked

${ }^{51}$ On the application of this philosophy in the US, see L. Cohen, A Consumer's Republic: The Politics of Mass Consumption in Postwar America (New York, 2003). 
the memory of the old Managua, designing a structure that would capture the vibrancy of the old city, but in-doors and accessible by automobile. A new mall at Nejapa offered a casa-ciudad, an indoor city to its customers. It would recreate the best the old city had to offer for a new middle class, but also offer an escapist sensation that 'you're not in Nicaragua'. ${ }^{52}$ The new Metrocentro mall directly south of the destroyed old city advertised itself, as seen in Figure 4, as Managua's new eje or 'axis'.

The other city, isolated from the consumer capitalism of the motorized Managua, was the city of the working poor. The centrepiece of the US reconstruction effort and the heart of the 'other' new Managua was the Las Américas housing project. USAID chose sites to the south-east of the old city centre for the new project, conceived as a temporary shelter programme to house the thousands of poor Managuans whose homes had been destroyed. Somoza's government rhetorically placed the new housing developments outside the new Managua, speaking glowingly of Nicaragua's new '3rd city'. Its population of 70,000 would follow only León and Managua itself. ${ }^{53}$ The sites for Las Américas 1, 2, 3 and 4 were chosen for their distance from seismic activity as well as their proximity to the city's industrial area where its residents would supposedly find employment. ${ }^{54}$ The project, which began in February of 1973 and was completed by May, built 11,000 shelters of wood and sheet metal. Each was a $15^{\prime} \times 15^{\prime}$ hut with dirt floors. In response to criticism in the US press that aid money was merely creating slums, USAID spokespersons asserted that Las Américas was not a 'housing' project but a 'shelter' project, designed to accommodate displaced Managuans as quickly as possible. ${ }^{55}$

Since USAID purportedly did not have funds to house Managua's poor adequately, the project relied on a process of 'self-help'. The inhabitants of Las Américas would be given assistance in the form of tools and planning advice in order to improve their houses themselves, converting them from temporary shelters into comfortable homes. The housing projects were beset by problems from the beginning. Managua's torrential rains during the winter season threatened to wash away the shelters, which had inadequate drainage systems. This rain notwithstanding, the government failed to provide potable water for its citizens. The Guardia provided some assistance in improving local infrastructure as part of its 'civic action' training, but apparently quickly lost interest when the community's demands became too much. It remained a presence nonetheless, monitoring the activities of residents and trying to assure that they worked in industry or construction. The Guardia kept the poorest refugees from migrating there, which led to the creation of even larger

\footnotetext{
52 'Un recorrido por la nueva', LP, 5 Sep. 1974.

53 'Las Américas: tercera ciudad de Nicaragua', LP, 1 Aug. 1974.

${ }^{54}$ NARA/NCF, box 10, Harrison Wehener, 'Housing'.

55 NARA/NCF, box 10, Charles Dean, letter to Washington Post, 23 May 1973.
} 


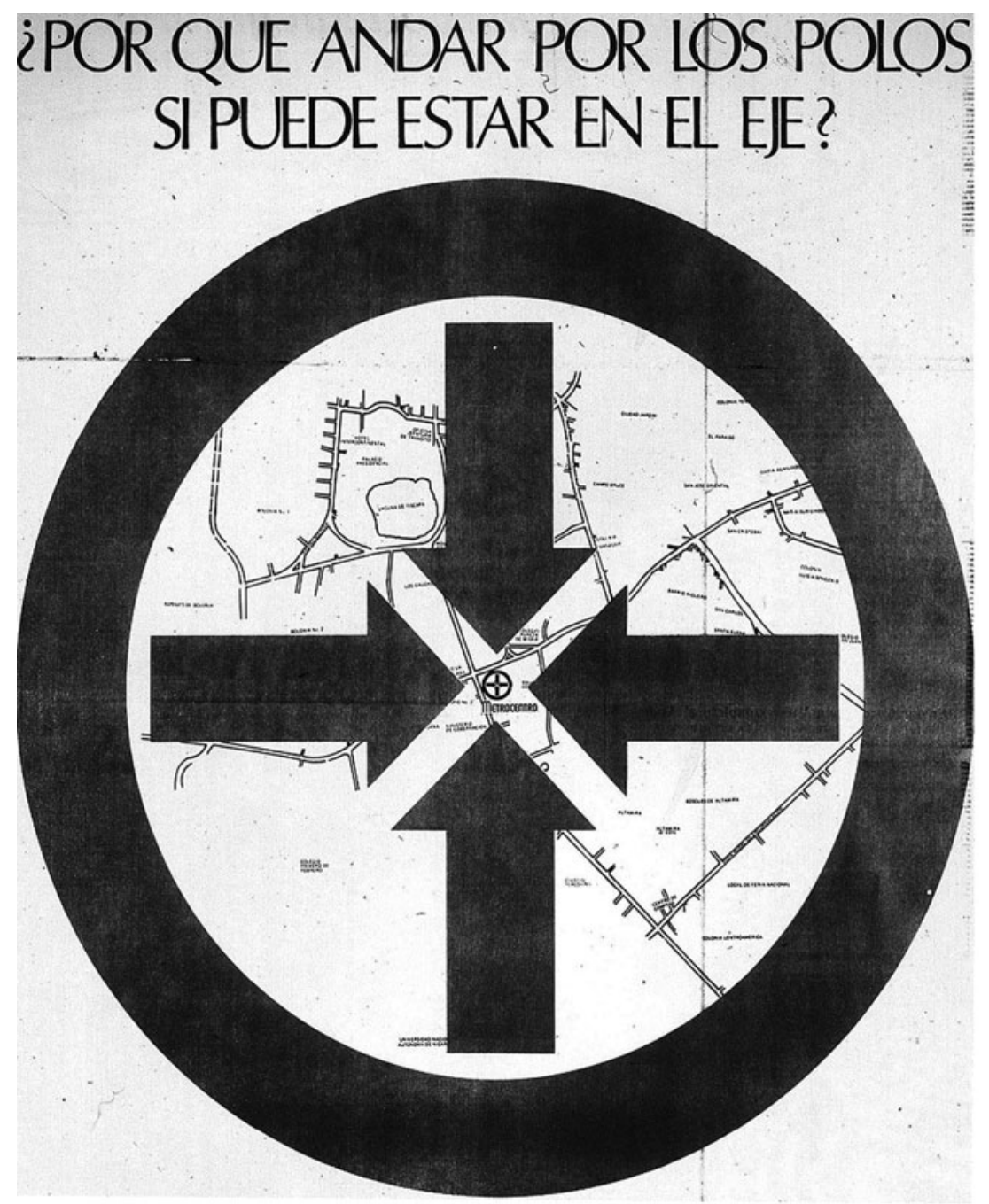

Figure 4: Advertisement for Managua's Metrocentro Mall: 'Why go to the poles when you can be at the centre?'

Source: La Prensa, 23 Nov. 1974.

illegal slums on the city's outskirts. ${ }^{56}$ The government attempted to create community organizations for the residents, but rather than building a grassroots organization, it used 'food for work' programmes to extract their labour. ${ }^{57}$

56 'US relief housing on way to becoming Managua slum', Washington Post, 18 May 1973, A17.

57 NARA/NCF, box 10, 'Community development in Las Américas', 17 Oct. 1973. 

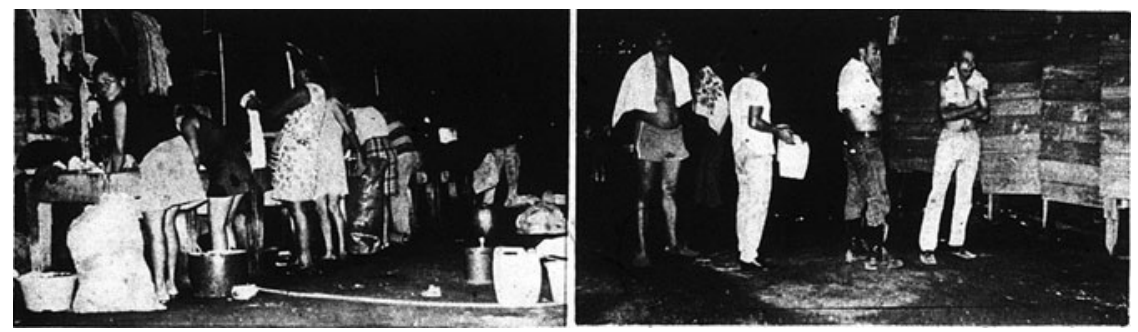

Figure 5: Dawn in Las Américas: residents using water stations in the night

Source: 'Madrugada en Las Américas', LP, 24 Aug. 1974.

The promise of employment for the people of Las Américas failed to materialize. In the neighbourhoods of old Managua, many lower-class people survived by providing goods and services for their wealthier neighbours. In Las Américas, however, the only neighbours were other people with comparably low incomes. This condition provided little opportunity for sustaining the small-scale commerce that was the lifeblood of mixed-class neighbourhoods before the earthquake. Transportation proved insufficient to carry the residents of the housing project to more affluent parts of Managua where they might find employment. ${ }^{58}$ The barrios lacked schools, health services, electricity and proper sanitation. ${ }^{59}$ Editorials in La Prensa lamented that deplorable conditions in Las Américas would bring about the moral as well as physical degradation of its inhabitants. They pointed out that the only thriving commercial activity in the neighbourhoods was vice. ${ }^{60}$

Receiving little assistance from authorized community organizations, the residents attempted to make their voices heard through committees to petition the government about the lack of reconstruction of their homes and the lack of services, but their complaints remained unanswered. All over the city, poor Managuans began to engage in spontaneous acts of violence to protest the government's deafness. Massive strikes of hospital and construction workers took place. In many cases, the strikes resulted in significant gains in those sectors, but they left the majority of the poor untouched. The issue of water finally pushed the residents of Las Américas toward rebellion. Residents had long complained of the water stations interspersed throughout the neighbourhoods. They only functioned from midnight until 6 a.m., causing residents to stand in long lines through the night (Figure 5). When the government finally responded

\footnotetext{
58 NARA, RG 59 Microfilm, P76049-1377, J. Theberge, 'Nicaragua - economic performance in 1975 and prospects for $1976^{\prime}, 31$ Mar. 1976.

59 'Informe oficial sobre desastre en Las Américas', LP, 7 Mar. 1974.

60 “'Las Américas" reconstrucción con cantinas', LP, 21 Feb. 1974.
} 
to their entreaties, it announced that the public water services would be removed and the residents would be charged to install taps in their homes. Riots broke out on the night of 7 October 1974. Residents destroyed the government-installed facilities. ${ }^{61}$ Managua's poor were clearly restive, unhappy with the attempts by their own and foreign governments to design better lives for them. Their concentration in working-class neighbourhoods gave them a new opportunity to unite but also improved the government's capacity to supervise them. Given the fractured nature of the anti-Somoza opposition at the national level, would the decentralized Managua allow them to voice their grievances or simply relegate them to the periphery?

\section{Managua and the anti-Somoza opposition}

The new Managua that was emerging in the years following the earthquake was changing, not just the old patterns of urban life but also the political life of the country. General Somoza succeeded in reshaping the city to augment both his personal wealth and political power, but simultaneously helped forge the coalition of workers, peasants, radical leftists and conservative elites that would unseat him in the 1979 revolution. One of the key explanations for the successful revolution which would overthrow Somoza in 1979, as opposed to its failure in countries with equally brutal regimes such as El Salvador and Guatemala, is that the Nicaraguan elite turned against Somoza precisely because he overstepped the boundaries set by the tacit (or sometimes explicit) agreement between the dynasty and the rest of the Nicaraguan elite, and attempted to garner too much power for himself. ${ }^{62}$ What this interpretation overlooks is that the shape of the new city itself forged this new revolutionary consciousness. The destruction of Managua's centre and the deformed city put in its place convinced many Nicaraguans of the emptiness at the centre of the US modernization project.

The nascent political opposition in Nicaragua objected to more than Somoza's heavy-handed attempts to use the reconstruction to garner wealth and power. Though the Nicaraguan opposition was perennially concerned about threats to its privilege, their businesses were thriving after the earthquake. The shape and structure of the 'new' Managua itself became the object of the opposition's distaste, its very modernity seen as the source of social ills which must be resisted. The axes of revulsion toward Somoza were twofold, and both complemented and contradicted one another. On the one hand, Somoza displayed an atavistic acquisitiveness of power and wealth. Members of the elite fretted that Somoza gathered wealth not for its own sake, since the enterprises he owned before the

61 'Rebelión en "Las Américas"', LP, 8 Oct. 1974.

62 R. Spalding, Capitalists and Revolution in Nicaragua: Opposition and Accommodation, 19791993 (Chapel Hill, 1994). 
earthquake had the potential to prosper should they be managed in a more efficient manner. ${ }^{63}$ What disturbed them was that his 'feudal' mentality meant that he gathered wealth not for profit but for personal control. On the other hand, the opposition argued, Somoza was too much in thrall to the 'modern'. He recklessly crisscrossed the city with new highways, creating an automobile friendly city to separate rich from poor while destroying an invaluable sense of community. ${ }^{64}$

The tie that bound these two disparate visions of Somoza, the feudal baron and the ruthless modernizer, was the United States itself. Somoza was ridiculed by the opposition as shamefully subservient to the Americans, who were in turn seen like Somoza himself as possessed of both immense power and cultural barbarism. ${ }^{65}$ Somoza's fawning behaviour toward US power was, however, an intentional attempt to distance himself from the Nicaraguan elite, siding instead with the Nicaraguan people. He offered himself to them as an 'indispensable man', the one who linked Nicaragua to the prosperity symbolized by the United States. ${ }^{66} \mathrm{He}$ used the signing of aid contracts as photo opportunities, courted US officials who travelled to Nicaragua and constantly sought the privilege of personal meetings with President Nixon.

The Nicaraguan private sector and nascent political opposition initially greeted the US vision of a modernized and decentralized Nicaragua with great hope. One of the pillars of the decentralization policy was the encouragement of healthy growth in other major cities of Nicaragua. The conservative oligarchy, whose base was in Granada, saw this prospect as a path to regaining some of their lost power and glory. Conservative intellectuals had called since the 1960s for a decentralization of population and industry from Managua. ${ }^{67} \mathrm{~A}$ political conference gathering the most important voices of the private sector held out hope that reconstruction would foster both economic growth and the return of their traditional power. $^{68}$

The voice of Nicaragua's political opposition, La Prensa editor Pedro Joaquín Chamorro, greeted warmly this idea of a decentralized Nicaragua. He was, however, highly critical not just of Somoza's avarice and subservience to the United States, but also of the private sector's eagerness to put their interests above that of the nation as a whole. He referred to the conservatives who participated in the 'pact' with Somoza as 'zancudos', blood-sucking mosquitoes that drained the life from the country. Chamorro argued that the disastrous earthquake had not just caused great physical and emotional harm to the Nicaraguan people.

63 NARA/NCF, box 10, 'Memorandum of conversation', 20 Aug. 1973.

64 Francisco Laínez, Terremoto '72: elites y pueblo (Managua, 1976), 7.

65 Diederich, Somoza and the Legacy of US Involvement.

66 'Somoza-viviendas, que significa?', LP, 30 Mar. 1974.

67 'Desarrollo urbano de Managua', Revista Conservador, 16 (1967), 78.

${ }^{68}$ NARA/NCF, box 10, Managua to Department of State, 'Economic and commercial highlights, May 1974'. 
Its consequences threatened the population's very identity. Chamorro compared the impact of the earthquake to that of the US marine occupation earlier in the century, which had brought about the hated Somoza dynasty in the first place. ${ }^{69}$

The literary voice of the anti-Somoza opposition was Pablo Antonio Cuadra, who built his reputation on the exposition of a distinctly Nicaraguan nationhood. To Cuadra, Managua was not becoming 'decentralized' but 'de-centred'. He compared the 1972 earthquake to the nineteenth-century invasion of filibuster William Walker, which had threatened national sovereignty but unified the Nicaraguan people. The earthquake, though a tragedy of similar scale to the filibuster invasion, fractured them. The new, decentralized city was dividing Managuans along fractious class lines. The middle classes in their automobiles were succumbing to an extreme individualism, which disconnected them both from each other and from the lower classes. Conversely, packed inside their buses Managua's poor were forming a new collective conscience, which threatened to explode into class warfare if not checked. ${ }^{70}$ 'A capital is a cathedral', Cuadra wrote. He warned ominously of the 'monstrous politics' such a capital as Managua might engender. ${ }^{71}$

While the pages of La Prensa provided the venue for the conservatively rooted anti-Somocismo, after the earthquake it also became the venue for a group of young, educated Nicaraguans to express their more radical opposition to the regime. Journalists like William Ramirez, Rosario Murillo and Bayardo Arce, all of whom would become leaders in the coming Sandinista revolution, used the paper to describe in detail the misery suffered by Nicaragua's poor. Whereas conservative critics such as Cuadra and Chamorro lamented the loss of community and national identity, the young militants described the formation of a new sense of community among Managua's poor. Speaking for the poor residents of Las Américas and imagining a version of 'self-help' independent of US control, Murillo wrote: 'Only we ourselves can solve our problems. Up to now what Las Américas has obtained has been through struggles and efforts of we who live here. ${ }^{72}$ She and others in the FSLN saw in the spontaneous organization and acts of violence in Managua's poor neighbourhoods hopeful signs of a growing class consciousness. Instead of fearing this consciousness as Pablo Antonio Cuadra did, they hoped to harness it in order to bring about a revolution.

An alternative design for the new Nicaragua was created by members of the elite and the radical left, which manifested their shared distaste for the direction in which Nicaragua was moving. It also helped engender

${ }^{69}$ P.J. Chamorro C., Richter 7 (Managua, 1976).

70 P.A. Cuadra, 'Nuestro capital y la burbuja del Nicaragüense', El Nicaragüense (Managua, 2007), 197.

${ }^{71}$ Ibid., 198.

72 R. Murillo, ‘Colonos 74 sub-viven en “Las Américas"”, LP, 28 Aug. 1974. 


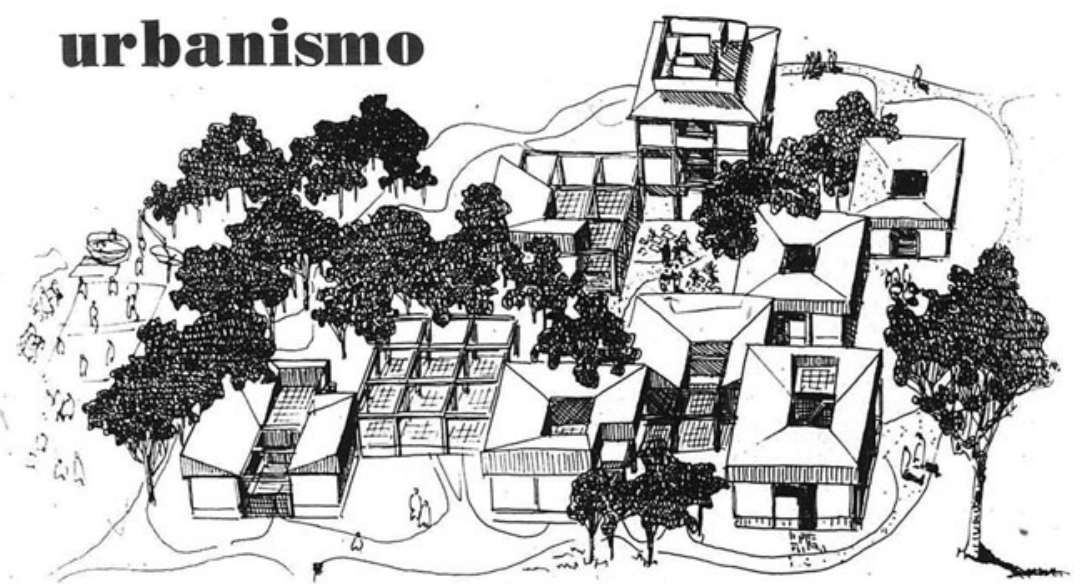

Figure 6: Artist's rendering of the 'El Paraíso' urban development Source: LP, 18 Aug. 1974.

the common perspective that would forge the future alliance which would overthrow Somoza. Father Miguel d'Escoto, a member of the Maryknoll order, founded in 1974 the Fundación Nicaragüense para el Desarrollo de una Comunidad Integral (FUNDECI), which brought together Nicaraguan and foreign architects and collected money from international organizations and from members of Nicaragua's elite to design and build a 'model' community in the city of León. It was funded by members of Nicaragua's elite who worked with the Somoza regime but also were beginning to seek alternatives. ${ }^{73}$

Designed by Chilean architect Jorge Gomez Ramos, 'El Paraíso' was conceived as a model community for working-class Nicaraguans, whose design was based on close study of the needs of the poor (Figure 6) ${ }^{74} \mathrm{In}$ contrast to the substandard housing projects in Managua, in the middle of this community would be a centre, housing a church, market, school and community meeting area. Chamorro asserted that such a community as 'El Paraíso' offered the semblance of middle-class living to the poor, and could lead to the 'reconstruction of man in Nicaragua'. ${ }^{75}$ Instead of living in a 'barracks or anthill' as he asserted the poor often did in Managua, the members of this model community would have affordable but welldesigned homes which they could alter to their taste. The community was explicitly designed to account for both the 'material' and 'spiritual'

\footnotetext{
73 “"El Paraíso” de Fundeci: un modelo piloto de urbanización comunitaria', LP, 18 Aug. 1974.

74 'De mil viviendas constará ciudadela El Paraíso-León', LP , 4 Mar. 1974.

75 'Un formidable proyecto social', $L P, 22$ Feb. 1974.
} 
needs of its inhabitants. D'Escoto's plan brought together the radical and conservative wings of the anti-Somoza opposition. He later played a key role in unifying the 'Group of 12 ', which brought together the FSLN and the bourgeois opposition and helped forge an international consensus that Nicaragua's dictatorship must fall. ${ }^{76}$

\section{Conclusion}

Managua's post-earthquake history provides a demonstration of the pivotal importance urban planning and design can have not just on one country, but on the international history in which it is embedded. Managua's fractured image became a figurative battleground, over which a dictator and his opponents fought for the right to determine their nation's future. It would soon become a literal battleground, as avenues for peaceful protest closed down. After a successful Sandinista assault on the home of Somoza supporter 'Chema' Castillo in December 1974, the dictator declared martial law and press censorship and initiated a campaign of harsh persecution of dissidents. Instead of turning to the dictator for protection, members of Nicaragua's elite began to collaborate with the leftist insurgents. The people of Managua and many other cities rose in revolt against the dictatorship in 1977, culminating in the 1979 overthrow of the decades-long dynasty.

Managua should be seen as a Cold War city both for the way geopolitical imperatives impinged on its urban fabric and the way its residents felt compelled to internationalize their struggle and seek alternative visions of modernity contrary to that proffered by the United States. After the revolution, the cross-class alliance created by the earthquake formed a Junta de Reconstrucción Nacional committed to undo the damage of the earthquake and the revolution. Nicaragua's new government turned to assistance from Cuba and the Soviet Union thanks to the history of collusion between the US government and Nicaragua's autocrats. The class alliance was unstable, and disaffection with the revolution stemmed in part from the new government's apparent willingness to replace a vision of modernity imported from the United States with one imported from Cuba, and the US funded Contra war accentuated these divisions. ${ }^{77}$ A new reconstruction of Managua would have to wait, but the city remained a bastion of revolutionary sentiment through the war and beyond.

After the Cold War, the virtues of decentralization became orthodoxy in neoliberal planning, discouraging attempts to re-centre the urban fabric. ${ }^{78}$

${ }^{76}$ Most accounts locate the beginning of this alliance later, after insurrection had begun. See Everingham, Revolution and the Multiclass Coalition in Nicaragua, 110-37.

77 P.A. Cuadra, 'Architectura y Lenguaje', LP, 7 Jun. 1980.

78 On decentralization and neoliberalism, C. Castañeda, Utopia Unarmed: The Latin American Left after the Cold (New York, 1993), 367; on neoliberal Nicaragua, see F. Babb, After Revolution: Mapping Gender and Cultural Politics in Neoliberal Nicaragua (Austin, 2001). 
Contemporary Managuans inhabit a fractured city, which author Erick Aguirre likens to living with an unburied corpse, a reminder of the Cold War's legacy. ${ }^{79}$ Despite this catastrophic history, the unlikely alliance between left and right created by the planning process demonstrates that the promise of urban space as community manifested in the world holds revolutionary possibilities.

${ }^{79}$ E. Aguirre, Subversión de la Memoria: Tendencias en la Narrativa Centroamericana de Postguerra (Managua, 2005), 164. 